Ecclesia. Studia z Dziejów Wielkopolski t. 12 (2017)

doi: $10.14746 /$ e.2017.12.5

\author{
LESZEK WILCZYŃSKI \\ Uniwersytet im. Adama Mickiewicza w Poznaniu \\ Wydział Teologiczny
}

\title{
Życie religijne mieszkańców Poznania pod okupacją niemiecką na przykładzie parafii Matki Boskiej Bolesnej
}

W XIX wieku nastąpił demograficzny i urbanistyczny rozwój Poznania. O ile w 1816 roku miasto liczyło 20.000 mieszkańców, o tyle w 1843 roku już 40.200 mieszkańców. Pół wieku później Poznaniu mieszkało 73.238 osób (1895), a w 1910 roku już 156.696 mieszkańców. Wydarzenia Wiosny Ludów 1848 roku sprawiły, że rząd w Berlinie przyspieszył proces germanizacji Wielkiego Księstwa Poznańskiego, a Poznania w szczególności. W 1816 roku Polacy stanowili 66,6\% mieszkańców Poznania. W 1848 roku ich udział w społeczności miejskiej zmniejszył się do 42,9\%. Dopiero samoorganizacja Polaków, połączona z wysiłkami organicznikowskimi, sprawiła, że w drugiej połowie XIX wieku trend spadkowy udało się odwrócić. W 1890 roku Polacy stanowili 50,7\% społeczności miejskiej, a w 1910 roku 57,1\% mieszkańców ${ }^{1}$.

Zgodnie z pruską polityką wojenną Poznań był miastem fortecznym, co powodowało liczne ograniczenia w jego rozwoju. System murów miejskich, wznoszony od 1828 roku, uniemożliwiał swobodny rozwój miasta. W 1816 roku obejmowało ono tylko śródmieście, ulicę Święty Marcin, Kondorf, Święty Wojciech, Chwaliszewo, Śródkę, Zawady i Świętego Rocha. Poza murami miejskimi znajdowały się osady Piotrowo, Berdychowo, Górna i Dolna Wilda, Łazarz, Górczyn, Jeżyce, Sołacz, Winiary, Rataje, Dębiec, Żegrze oraz Bonin. Dopiero w 1896 roku przyłączono do miasta Berdychowo i Piotrowo, lecz

${ }^{1}$ M. Kędelski, Ludność Lazarza i Górczyna w XIX i na początku XX wieku, „Kronika Miasta Poznania” (dalej: KMP), nr 3: Święty Lazarz, 1998, s. 11; S. Salmanowicz, Prusy. Dzieje państwa i społeczeństwa, Warszawa 1998, s. 289; M. i L. Trzeciakowscy, W dziewiętnastowiecznym Poznaniu. Życie codzienne miasta 1815-1914, Poznań 1982, s. 68; L. Trzeciakowski, Stosunki polsko-niemieckie w Wielkim Księstwie Poznańskim w latach 1846-1848, [w:] W kręgu polityki. Polacy-Niemcy w XIX wieku, red. L. Trzeciakowski, Poznań 2002, s. 218-219. 
przełomem było przyjęcie przez sejm pruski ustawy z 30 marca 1900 roku, znoszącej forteczny charakter Poznania i umożliwiającej przyłączenie do niego Wildy, Łazarza, Górczyna i Jeżyc. Zapoczątkowało to okres gwałtownego rozwoju stolicy Wielkopolski².

Proces łączenia Łazarza i Górczyna z miastem został zapoczątkowany już pod koniec XIX wieku. Ustanowiono wówczas podstawową siatkę ulic (1896), rozpoczęto też budowę trasy tramwajowej w kierunku Górczyna (1898), a jej ukoronowaniem było powstanie zajezdni tramwajowej przy ulicy Głogowskiej (1906-1908). W 1898 roku utworzono przy tej samej ulicy ogród botaniczny (obecnie Park Wilsona), a w 1903 roku władze miasta ustanowiły plan zagospodarowania przestrzennego dla dzielnicy, co zapoczątkowało w niej szybki rozwój budownictwa mieszkaniowego. Obie dzielnice rozwijały się jednak nierównomiernie. O ile na Łazarzu rozkwitała typowa zabudowa kamieniczna, o tyle Górczyn zachował charakter wiejskiego przedmieścia ${ }^{3}$.

Zwycięskie powstanie wielkopolskie spowodowało masową emigrację licznej niemieckiej mniejszości narodowej. W 1910 roku ludność Poznańskiego w 38,4\% stanowili Niemcy, lecz do 1931 roku udział Niemców w społeczności regionu spadł do 9,2\%. Jeszcze bardziej spadek ten widoczny był w populacji Poznania, gdzie udział ludności pochodzenia polskiego wzrósł do 93,7\%, m.in. dzięki napływowi z Niemiec tysięcy Polaków. Rozkwit przemysłu, handlu i usług, w połączeniu z rozwojem urbanistycznym miasta w okresie międzywojennym umożliwił zaabsorbowanie przybyszów i wzrost liczby jego mieszkańców ze 157.000 (1910) do 246.000 w 1931 roku i 265.000 u schyłku okresu międzywojennego (1937). Wzrost ten widoczny był także na Łazarzu i Górczynie. Obie dzielnice liczyły w 1921 roku 30.630 mieszkańców. W ciągu dekady liczba ta wzrosła o 49,3\%, a w 1938 roku wynosiła ona 56.911 mieszkańców. Nie bez znaczenia dla rozwoju obu zachodnich dzielnic miasta był stosunkowo wysoki komfort życia, dobre skomunikowanie dzielnic z pozostałymi częściami miasta, a także elitarny charakter Łazarza. Prestiż tej dzielnicy wzrósł szczególnie po modernizacji ogrodu botanicznego (1925-1926) i wybudowaniu kompleksu Pewuki (1929), ale duże znaczenie dla atrakcyjności obu dzielnic miało też ciekawe połączenie nowoczesnego, miejskiego stylu Łazarza z wiejskim charakterem sąsiedniego Górczyna. Wszystko to sprawiało, że społeczeństwo omawianych dzielnic było bardzo zróżnicowane pod względem wieku, pochodzenia społecznego i wykonywanego zawodu ${ }^{4}$.

${ }^{2}$ Z. Boras, L. Trzeciakowski, $W$ dawnym Poznaniu, Poznań 1974, s. 352.

${ }^{3}$ P. Dutkiewicz, Tramwaje w Poznaniu, Poznań 2005, s. 17, 228; Z. Dworecki, Poznań i poznaniacy w latach Drugiej Rzeczpospolitej 1918-1939, Poznań 1994, s. 83; M. Kędelski, Ludność Łazarza i Górczyna, s. 21-24.

${ }^{4}$ Z. Zakrzewski, Ulicami mojego Poznania. Przechadzki z lat 1918-1939, Poznań 1985, s. 561-569; Z. Zakrzewski, Przechadzki po Poznaniu lat międzywojennych, Poznań 1983, s. 267; 
Zróżnicowanie narodowościowe Łazarza i Górczyna przed 1918 rokiem wpłynęło na oblicze religijne mieszkańców. W 1843 roku katolicy stanowili 93,1\% społeczności obu dzielnic, lecz wraz z napływem niemieckich kolonistów, urzędników i wojskowych, głównie wyznania protestanckiego, udział katolików zmalał do 52,7\% w 1910 roku. W tym samym czasie udział protestantów wzrósł z 6,9\% do 44,6\% ${ }^{5}$. Niezależnie od wahań liczbowych obie wspólnoty wyznaniowe cierpiały z powodu niedostosowania sieci parafialnej, której rozwój nie szedł w parze z postępującą urbanizacją Łazarza i Górczyna. Nie bez wpływu na ten stan rzeczy - w przypadku katolików - miała realizowana przez Prusaków polityka walki z Kościołem katolickim. Obie omawiane dzielnice należały obszarowo do rozległej parafii św. Marcina. Znaczna odległość, utrudnienia komunikacyjne i konieczność przejścia kordonu wojskowego utrudniały życie religijne. Wiadomo, że rolę kościoła filialnego dla Łazarza i Górczyna spełniała niewielka świątynia pod wezwaniem św. Łazarza, znajdująca się przy Bramie Wildeckiej. Kościół ten - ze względu na zły stan techniczny - został w 1837 roku rozebrany, lecz pamięć o nim pozostała ${ }^{6}$.

Inicjatywa budowy kościoła na Łazarzu narodziła się pod koniec XIX wieku. Propagatorem tego pomysłu był Napoleon Urbanowski, właściciel miejscowej fabryki maszyn rolniczych, zaś po śmierci Napoleona (1896) jego syn Witold. Rzeczywisty pierwszy krok ku budowie świątyni uczynił jednak skromny rolnik łazarski, Józef Schneider, darowując na zbożny cel działkę pod budowę kościoła (29 VIII 1895). Pomysł popierał proboszcz parafii świętomarcińskiej, ks. Jan Lewicki (1846-1909), który wszedł do powołanego jesienią 1895 roku Komitetu Budowy Kościoła. Z dniem 6 lipca 1896 roku Komitet stał się prawnym posiadaczem działki budowlanej, a 4 sierpnia 1896 roku ks. Jan Lewicki poświęcił grunt pod budowę świątyni ${ }^{7}$.

Projekt kościoła opracował Michał Wilczewski, architekt z Wronek, lecz jeszcze przez trzy lata wierni z Łazarza i Górczyna nie mogli przystąpić do inwestycji z powodu oporu administracji niemieckiej. Ostatecznie, w wyniku silnej presji wywieranej na władze przez Konsystorz poznański, 19 lipca 1899

Z. Dworecki, Poznań i poznaniacy, s. 131, 133, 137; L. Trzeciakowski, Lata międzywojenne, [w:] Poznań. Zarys dziejów, red. J. Topolski, Poznań 1973, s. 85-87; S. Kowal, Społeczeństwo Lazarza w dwudziestoleciu międzywojennym, KMP, nr 3: Święty Łazarz, 1998, s. 108-113.

${ }^{5}$ M. Kędelski, Ludność Eazarza i Górczyna, s. 14.

${ }^{6}$ Archiwum Parafialne Parafii Matki Boskiej Bolesnej w Poznaniu (dalej: AP MBB), Kronika parafii MB Bolesnej 1896-1958, część I, karta „1896 rok”; Kalendarz kościelny parafii Matki Boskiej Bolesnej na św. Łazarzu w Poznaniu, Poznań 1939, s. 15.

${ }^{7}$ P. Matusik, Mater Dolorosa. U początków parafii Matki Boskiej Bolesnej na Świętym Łazarzu (1895-1913), KMP, nr 3: Święty Łazarz, 1998, s. 56-57; H. Szatkowski, Lewicki Jan Chrzciciel (1846-1909), [w:] Księża spolecznicy w Wielkopolsce 1894-1919. Stownik biograficzny, t. III, red. H. Szatkowski, L. Wilczyński, Gniezno 2007, s. 222-225; Album Przewodnika Katolickiego, nr 14, 1903; AP MBB, Kronika parafii MB Bolesnej 1896-1958, cz. I, karta „1897 rok”, s. 2. 
roku uzyskano od władz pruskich zgodę na rozpoczęcie budowy. Pierwsze prace rozpoczęto już jesienią 1899 roku, lecz nabrały one tempa dopiero rok później. W 1901 roku zakończono budowę dachu oraz wzniesiono ażurową wieżę, wykonaną przez zakłady Hipolita Cegielskiego. Wykończono także wnętrze świątyni. Łącznie na budowę obiektu zużyto 1.154 .950 cegieł oraz cztery wagony cementu, a koszt inwestycji wyniósł 301.468 marek. Dopełnienie odbioru technicznego przez urzędy pruskie umożliwiło konsekrację kościoła przez arcybiskupa Floriana Stablewskiego 15 września 1901 roku. Wyposażenie świątyni, wciąż będącej filią parafii św. Marcina, nie było kompletne. Wprawdzie od samego początku wieża kościoła wyposażona była w dzwony, lecz organy postawiono w 1905 roku, a drogę krzyżową dopiero w 1931 roku. Zakupu wyposażenia świątynnego i paramentów dokonano z ofiar wiernych i darowizn od majętnych mieszkańców Łazarza i Górczyna ${ }^{8}$.

Z chwilą konsekracji kościoła władze duchowne archidiecezji poznańskiej mianowały do sprawowania posługi duszpasterskiej ks. Edmunda Wagnera. Duchowny zainicjował życie wewnętrzne łazarskiego kościoła filialnego, powołując pierwsze organizacje apostolskie i kółko ministranckie, a także przystąpił do budowy probostwa (1902). Umożliwiło to zainicjowanie starań o wyodrębnienie dla Łazarza i Górczyna samodzielnej parafii (1904-1911), ale ze względu na obowiązujące przepisy prawa cywilnego nie było to łatwe. Sprawę skomplikowała śmierć arcybiskupa Floriana Stablewskiego (1906) i proboszcza Jana Lewickiego (1909).

Tymczasem rozwijało się życie duchowe łazarsko-górczyńskiej wspólnoty religijnej, w czym niemałą zasługę miał mianowany wikariuszem kościoła na Łazarzu ks. Kazimierz Maliński (1872-1928). Poza utworzeniem nowych stowarzyszeń katolickich i zaproszeniem do współpracy organizacyjnej kół przemysłowych wikariusz doprowadził do powstania cmentarza na Górczynie (1910-1911). Z dniem 1 stycznia 1913 roku ks. Maliński został mianowany proboszczem powołanej parafii Matki Boskiej Bolesnej. Życie religijne wspólnoty kwitło i dopiero wybuch I wojny światowej oraz przeciągające się walki na frontach Wielkiej Wojny przerwały ten rozwój. Ograniczenia cenzuralne i przepisy wojenne ograniczyły swobodę organizowania się ludności. W 1917 roku władze skonfiskowały na potrzeby wojenne dzwony kościelne, co tylko umocniło mieszkańców Łazarza i Górczyna, szczególnie zaś młodzież, w oporze przeciwko Prusakom. Patriotyczna postawa wiernych obu dzielnic sprawiła, że już wkrótce prasa niemieckojęzyczna zaczęła określać tutejszą parafię najtwardszą ostoją polskości w Poznańskiem. Z chwilą wybuchu powstania

\footnotetext{
${ }^{8}$ Tamże, część I, karta „1900 rok”, „1901 rok”, s. 1; P. Matusik, Mater Dolorosa, s. 61. - Wymieniony w kronice parafialnej koszt dzwonów, organów i podstawowego wyposażenia świątynnego wyniósł 59.266 marek niemieckich.
} 
wielkopolskiego spotkało się ono z poparciem parafian. Za czynem zbrojnym gorąco opowiadał się proboszcz Kazimierz Maliński. O wsparcie walczących apelowano bardzo często na łamach parafialnych „Wiadomości Kościelnych”.

Odzyskanie niepodległości przez Polskę było w historii parafii bardzo owocnym czasem. Liczba wiernych tylko w ciągu pierwszej dekady po 1918 roku podwoiła się. Nie tylko to było powodem zadowolenia łazarskiego duchowieństwa. Także gorliwość parafian była wzorowa. W latach 20 . XX wieku w nabożeństwach niedzielnych uczestniczyło średnio około 80\% wiernych, dekadę później 90\%. Rozwój demograficzny parafii, a także rosnące potrzeby duszpasterskie sprawiły, że w 1935 roku posługę sprawowało w niej dziewięciu kapłanów. Już z początkiem lat 20 . XX wieku rozpoczęto ważne inwestycje. W 1921 roku podjęto starania o wyodrębnienie z parafii łazarskiej osobnej placówki duszpasterskiej na Górczynie. W 1922 roku ukończono elektryfikację świątyni. Rok później przystąpiono do malowania jej wnętrza, a w 1925 roku założono chór kościelny ${ }^{10}$. Z dniem 1 maja 1928 roku władza duchowna mianowała proboszczem ks. Józefa Gorgolewskiego. Jego zasługą było uporządkowanie spraw materialnych parafii, a ich ukoronowaniem była spłata dawnego zadłużenia wobec parafii św. Marcina (1931). Proboszcz przyspieszył także prace nad usamodzielnieniem przyszłej parafii górczyńskiej. Wspomnieć też należy o wybudowaniu w latach 1928-1929 po wschodniej stronie terenu parafii Groty Matki Boskiej Bolesnej. Wkrótce utworzono też Komitet Budowy Domu Katolickiego (1931), chociaż do rzeczywistej budowy przystąpiono dopiero w 1938 roku. Inwestycji nie zdążono ukończyć przed wybuchem II wojny światowej ${ }^{11}$.

W parafii kwitło życie religijne, duchowe i kulturalne. Od 1918 roku ukazywało się pismo parafialne „Wiadomości Kościelne”, które u schyłku dwudziestolecia międzywojennego poszerzono o nowe działy. Dynamicznie rozwijała się Akcja Katolicka, zrzeszając liczne wspólnoty: eucharystyczne, maryjne, apostolstwa dorosłych i dzieci, misyjne i dobroczynne. W 1938 roku parafia Matki Boskiej Bolesnej liczyła 27.386 dusz, z czego w stowarzyszeniach parafialnych udzielało się niemal $32 \%$ wiernych $^{12}$.

${ }^{9}$ N. Kowalski, H. Szatkowski, Kazimierz Maliński (1872-1928), [w:] Księża społecznicy w Wielkopolsce 1894-1919. Stownik biograficzny, t. II, red. L. Wilczyński, H. Szatkowski, Gniezno 2007, s. 269-271; P. Matusik, Mater Dolorosa, s. 71; AP MBB, Kronika parafii MB Bolesnej 1896-1958, cz. I, karta „1918 rok”.

${ }^{10}$ Tamże, karta „1922 rok”, karta „1923 rok”; AP MBB, Kronika parafii MB Bolesnej 1896-1958, cz. II (Suplement), karta: „Uzupełnienia do różnych lat”.

11 AP MBB, Kronika parafii MB Bolesnej 1896-1958, cz. I, karta „1935 rok”; AP MBB, Sprawozdania duszpasterskie, cz. I, Sprawozdanie duszpasterskie za 1938 rok, s. 3-4.

${ }^{12}$ AP MBB, Kronika parafii MB Bolesnej 1896-1958, cz. II (Suplement), karta „Uzupełnienia do różnych lat" (1938 rok), s. 2. 
Wiadomości o nagłym pogorszeniu stosunków polsko-niemieckich były zaskoczeniem dla mieszkańców Łazarza i Górczyna. Parafianie szybko odpowiedzieli na apele władz cywilnych i kościelnych, przystępując do pożyczki narodowej na cele obronne. $Z$ niepokojem przyjęto z początkiem września 1939 roku informacje o ewakuacji władz, a także arcybiskupa poznańskiego Augusta Hlonda, który zarząd nad archidiecezją przekazał biskupowi pomocniczemu - Walentemu Dymkowi (3 IX 1939). Z dniem 5 września 1939 roku władzę nad miastem przejął jego dawny prezydent - Cyryl Ratajski, wkrótce obejmując również opuszczony urząd wojewody. Jego urzędowanie nie trwało długo, już bowiem 10 września 1939 roku do Poznania zaczęły wkraczać czołowe oddziały niemieckie, a 12 września 1939 roku miasto zostało całkowicie zajęte przez Niemców ${ }^{13}$.

Z chwilą wkroczenia do Poznania Niemcy przystąpili do tworzenia władz okupacyjnych, na czele których stanął Arthur Greiser. Wbrew prawu międzynarodowemu Poznańskie zostało wcielone do III Rzeszy (8 X 1939). Wprowadzono nowy, rygorystyczny system prawny, sprowadzający Polaków do roli obywateli drugiej kategorii, pozbawionych podstawowych swobód i wolności ${ }^{14}$. Jednym z kluczowych zadań administracji okupacyjnej było zniszczenie struktur Kościoła katolickiego. Niemcy dobrze pamiętali o roli, jaką w kształtowaniu postaw patriotycznych Polaków odgrywali przed 1918 rokiem księża. Plan ten realizowano już od pierwszych dni II wojny światowej, mordując kapłanów (od 1 września do 25 października 1939 zginęło 19 duchowych z archidiecezji poznańskiej), zamykając lub niszcząc kościoły. Kolejna wielka fala aresztowań wśród księży archidiecezji gnieźnieńskiej i poznańskiej, przeprowadzona w czasie od stycznia do marca 1940 roku, obejmująca 284 kapłanów, doprowadziła do załamania struktur Kościoła katolickiego w Wielkopolsce. Niemcy uznali pozbawione proboszczów i wikariuszy parafie za „wygasłe” placówki duszpasterskie, co stanowiło pretekst do zamknięcia kościołów ${ }^{15}$.

${ }^{13}$ L. Wilczyński, Kardynat August Hlond - wrześniowy uciekinier?, „Poznańskie Zeszyty Historyczne”, t. IX, 2007, s. 47-49; A. Zarzycki, Cyryl Ratajski (1875-1942), KMP, nr 3, 1989, s. 74-97. - Na temat początków okupacji niemieckiej w Poznaniu patrz także: Z. Szymankiewicz, Poznań we wrześniu 1939 roku, Poznań 1985; Wysiedlenie i poniewierka 1939-1945. Wspomnienia Polaków wysiedlonych przez okupanta hitlerowskiego z ziem polskich «wcielonych» do Rzeszy, red. C. Łuczak, Poznań 1974; Z. Zakrzewski, Wspominam Poznań. Fakty i refleksje, Poznań 1986.

${ }^{14}$ Obszerniej patrz także: C. Łuczak, Pod niemieckim jarzmem (Kraj Warty 1939-1945), Poznań 1996; E. Serwański, Wielkopolska w cieniu swastyki, [w:] Zbrodnie niemieckie $w$ Wielkopolsce 1939-1945, red. M. Libicki, R. Wryk, Poznań 2004; C. Epstein, Wzorcowy nazista. Arthur Greiser i okupacja Kraju Warty, Wrocław 2010.

${ }^{15}$ W. Jacewicz, J. Woś, Martyrologium polskiego duchowieństwa rzymskokatolickiego pod okupacja hitlerowska w latach 1939-1945, z. I: Straty osobowe, Warszawa 1977, s. 17-19, 24; K. Jarkiewicz, W ogniu wypróbowany 1939-1945, [w:] Dzieje Kościoła w Polsce, red. A. Wiencek, Bielsko-Biała 2008, s. 404; K. Śmigiel, Duchowieństwo polskie w tzw. Okręgu Warty 1939-1945, [w:] Zbrodnie niemieckie w Wielkopolsce, red. M. Libicki, R. Wryk, Poznań 2004, s. 130. 
Według danych niemieckich do końca grudnia 1939 roku w tzw. Kraju Warty zamknięto 97\% kościołów. W archidiecezji poznańskiej czynnych pozostawało 16 świątyń, z czego w Poznaniu cztery (1939), a od 1940 roku już tylko dwie placówki.

Łazarska parafia Matki Boskiej Bolesnej nie ucierpiała bezpośrednio w wyniku działań wojennych we wrześniu 1939 roku, choć niemieckie lotnictwo zbombardowało okolice Dworca Głównego, targów poznańskich oraz zabudowania przy ulicy Wyspiańskiego, gdzie mieściła się placówka Polskiego Czerwonego Krzyża. Działania wojenne, a później zajęcie Poznania przez Niemców, wywołały u parafian oczywisty niepokój. Obawy te próbowali gasić księża, nawołując jednocześnie wiernych - zgodnie z apelem poznańskiego wikariusza generalnego, biskupa Walentego Dymka - do zachowania spokoju i nieangażowania się $\mathrm{w}$ działania, mogące narazić ich na niebezpieczeństwo (21 IX 1939) ${ }^{16}$. Uspokojenie nastrojów wiernych nie było możliwe, skoro byli oni świadkami aresztowań duchownych. Już we wrześniu 1939 roku Niemcy aresztowali dwóch prefektów ze szkół należących do parafii Matki Boskiej Bolesnej (księży Edwarda Piętkę i Antoniego Czwojdzińskiego) oraz mieszkających na Łazarzu i pomagających w pracy duszpasterskiej przy parafii księży Antoniego Banaszaka oraz Stanisława Szymańskiego.

W początkowym okresie okupacji stałą posługę duszpasterską na Łazarzu i Górczynie sprawowali proboszcz Józef Gorgolewski oraz wikariusze Edmund Lorkiewicz, Roman Hildebrandt, Alfons Jankowski i Marian Frankiewicz. Była to liczba niewystarczająca, zważywszy na rychłe zamknięcie większości kościołów w Poznaniu, co znów oznaczało, że parafia Matki Boskiej Bolesnej obejmowała odtąd swym zasięgiem połowę miasta (drugą czynną placówką była parafia św. Wojciecha). Zogniskowanie życia religijnego wokół parafii na Łazarzu natychmiast wzmogło czujność Gestapo i niemieckich donosicieli. Szczególnie częstym gościem w biurze parafialnym był od jesieni 1939 roku Niemiec z Murowanej Gośliny nazwiskiem Faelsch, płynnie mówiący po polsku. Najprawdopodobniej w wyniku jego denuncjacji doszło do aresztowań wśród księży oraz osób ukrywających się przed okupantem ${ }^{17}$.

Zgodnie z zarządzeniem biskupa Walentego Dymka z 25 września 1939 roku w czynnych parafiach należało przywrócić pełne życie liturgiczne. Realizacja tego zarządzenia nie była możliwa wobec restrykcji i ograniczeń, jakie narzucili Kościołowi katolickiemu Niemcy. Już samo obowiązywanie godziny policyjnej i ograniczenie swobody poruszania ludności polskiej uniemożliwiało odprawianie nabożeństw wieczornych, ale ustanowienie przez okupan-

${ }^{16}$ Ł. Jastrząb, Życie religijne w Poznaniu podczas okupacji niemieckiej (1939-1945). Część I, „Poznańskie Zeszyty Humanistyczne”, t. XXIV, 2016, s. 32.

${ }^{17}$ AP MBB, M. Frankiewicz, Wspomnienia z lat okupacji 1939-1945, maszynopis, s. 14-15. 
ta 31 grudnia 1939 roku rygorów administracyjnych wobec Kościoła jeszcze bardziej ograniczyło życie religijne parafian. Od tego dnia nabożeństwa wolno było odprawiać tylko w niedziele i święta w wyznaczonych godzinach $(9,9.45,10.30)$, a wierni mogli w nich uczestniczyć tylko we wnętrzu kościoła, gdyż gromadzenie się przed świątynią było zabronione ${ }^{18}$.

Ograniczenia swobód religijnych dla katolików w Poznaniu wprowadzone pod koniec 1939 roku były dopiero zapowiedzią nadchodzących restrykcji. Z początkiem 1940 roku Niemcy zakazali odprawiania nabożeństw w święto Trzech Króli, następnie w uroczystość apostołów Piotra i Pawła i na Wszystkich Świętych. Nabożeństwa majowe wolno było odprawiać tylko w niedziele i święta. Zakazano odbywania publicznych procesji w święto Bożego Ciała (dozwolone tylko w obrębie murów kościelnych). W październiku 1940 roku zakazano odprawiania nabożeństw różańcowych, a przed nadchodzącym Bożym Narodzeniem zabroniono roznoszenia po domach opłatków ${ }^{19}$. Rok później Niemcy znieśli w oficjalnym kalendarzu święto Trzech Króli, a wkrótce zakazano także sypania głów popiołem w środę popielcową ${ }^{20}$. Ograniczenia te Niemcy thumaczyli przewrotnie troską o polskich katolików i „brakiem czasu" po ich stronie na poświęcanie się życiu religijnemu, co było wynikiem zaangażowania ludności polskiej w prace przymusowe na rzecz niemieckiego okupanta. Z podobnych przyczyn - „braku czasu” - przed Wielkanocą w 1941 roku zakazano świętowania Wielkiego Tygodnia. Wierni mogli udać się do kościoła Matki Boskiej Bolesnej dopiero w Wielką Sobotę, i to tylko w wybranych godzinach. W tym samym roku zakazano parafianom łazarskim klękania i modlenia się przed Grotą Matki Bożej ${ }^{21}$.

Już z końcem 1940 roku administracja tzw. Kraju Warty podjęła działania na rzecz trwałego rozdzielenia katolików polskich i niemieckich. Z dniem 9 grudnia 1940 roku zakazano Niemcom uczestnictwa w mszach dla katolików polskich, a polskim duchownym udzielania sakramentów wiernym pochodzenia niemieckiego. Wkrótce wprowadzono dodatkowe restrykcje, uniemożliwiające np. polskim ministrantom udział $\mathrm{w}$ uroczystościach pogrzebowych Niemców ${ }^{22}$. Wszystkie te działania podyktowane były chęcią ostatecznego rozbicia jedności Kościoła katolickiego na ziemiach okupowanych i zerwania kontaktu ze Stolicą Apostolską. Temu służyło zaprowadzenie różnic między nielicznym duchowieństwem polskiego pochodzenia i księżmi-Niemcami. Istnienie obok siebie różnych grup duchownych i wiernych, a nawet placówek duszpasterskich pierwszej (niemieckiej) i drugiej (polskiej) kategorii w spo-

\footnotetext{
${ }^{18}$ AP MBB, Kronika parafii MB Bolesnej 1896-1958, cz. II (Suplement), karta „1939 rok”.

${ }^{19}$ Tamże, karta „1940 rok”, s. 1-6.

${ }^{20}$ Tamże, karta „1941 rok”, s. 1-3.

${ }^{21}$ Tamże.

${ }^{22}$ Ł. Jastrząb, Życie religijne w Poznaniu, cz. I, s. 44.
} 
sób oczywisty przeczyło braterstwu religijnemu. Parafia Matki Boskiej Bolesnej uzyskała status tzw. kościoła polskiego 22 czerwca 1941 roku. Data nie była nieprzypadkowa, gdyż tego samego dnia Niemcy dokonali agresji na Związek Radziecki. W żaden sposób nie wpłynęło to na polepszenie stosunku okupanta do ludności polskiej. Stało się wprost odwrotnie - restrykcje narastały. Pod pretekstem ochrony ludności Poznania przed skutkami nalotów bombowych Niemcy zakazali otwierania kościołów w dzień po ogłoszeniu alarmu przeciwlotniczego. Oznaczało to wprowadzenie administracyjnego zakazu odprawiania mszy niedzielnych ${ }^{23}$. Agresja na Związek Radziecki spowodowała konieczność zwiększenia wysiłku wojennego, co dla ludności polskiej w tzw. Kraju Warty oznaczało podniesienie norm pracy. Posłużyło to Niemcom do wprowadzenia dalszych ograniczeń życia religijnego, wynikających z „braku czasu”. Z dniem 21 września 1941 roku zabroniono parafii łazarskiej organizowania odpustu na święto Matki Boskiej Bolesnej (proboszczowi pozwolono odprawić sumę, ale zakazano nawet skromnej procesji wewnątrz kościoła ${ }^{24}$, od 12 października 1941 roku z powodu „braku czasu” zakazano głoszenia kazań w trakcie mszy, zaś 19 października 1941 roku zabroniono księżom odwiedzania chorych w domach. Jak już wspomniano, w tym samym roku zniesiono święto Wszystkich Świętych, co zapobiegać miało „zbiegowiskom” na cmentarzach. Zakazano wiernym udziału w uroczystościach Dnia Zadusznego (,zbiegowisko"), do końca roku zniesiono święto Niepokalanego Poczęcia NMP, a także - zgodnie z rasistowską zasadą darwinizmu społecznego - zabroniono katolikom wspierania potrzebujących ${ }^{25}$.

Sukcesy odnoszone w wojnie ze Związkiem Radzieckim zachęciły Niemcy do dalszego ograniczenia swobód religijnych Polaków i wprowadzenia kolejnych restrykcji. Cenzurą objęto śpiew kościelny, zakazując intonowania w trakcie mszy „nieprawomyślnej” pieśni Boże, coś Polskę. Zgodnie z postanowieniem administracji niemieckiej wyznaczono parafii łazarskiej tygodniowy termin (14-21 X 1941) na oddanie przez wiernych śpiewników zawierających słowa tej pieśni. Odtąd posiadanie śpiewników ze słowami Boże, coś Polskę oznaczało ryzyko poważnych konsekwencji ${ }^{26}$.

Życie łazarskiej wspólnoty parafialnej zostało ograniczone do minimum. Wiele zakazów i ograniczeń Niemcy wydali celowo, aby uniemożliwić wiernym kontakt z duchowieństwem i ograniczyć udział w liturgii. Ciągłe zmiany wprowadzane przez Niemcy utrudniały proboszczowi Józefowi Gorgolewskiemu, a później administratorom Alfonsowi Jankowskiemu i Marianowi Frankiewiczowi, zarządzanie rozległą parafią. Biuro parafialne mogło być

\footnotetext{
${ }^{23}$ AP MBB, Kronika parafii MB Bolesnej 1896-1958, cz. II (Suplement), karta „1941 rok”, s. 1-3.

${ }^{24}$ Tamże, s. 5.

25 Tamże, s. 7.

${ }^{26}$ Tamże, s. 5.
} 
czynne tylko godzinę tygodniowo, w niedzielę (w godzinach 11-12), co w sposób oczywisty uniemożliwiało załatwienie spraw interesantów. W połowie 1941 roku Niemcy dopuścili możliwość pracy biura parafialnego także w środy, ale w późnych godzinach popołudniowych. Decyzja ta tylko pozornie sprzyjała katolikom, gdyż w dni powszednie Polacy uczestniczyli w pracy na rzecz okupanta, a ponadto wielu nie miało odwagi ryzykować późnego powrotu do domu i groźby aresztowania podczas godziny policyjnej. Drastyczne ograniczenie możliwości korzystania z biura parafialnego było nadzwyczaj niekorzystne, chociażby dla narzeczonych, zobowiązanych do udziału w naukach przedmałżeńskich i dopełnienia formalności. Ze względów bezpieczeństwa już od 1939 roku biuro parafialne zaprzestało publikowania informacji na parafialnej tablicy ogłoszeniowej (zgony, śluby, przygotowania do sakramentów), co zubożyło życie wewnętrzne łazarskiej parafii ${ }^{27}$.

Poważnym i uciążliwym ograniczeniem było zmniejszenie czasu na udzielanie wiernym sakramentu pokuty. Do wiosny 1940 roku księża spowiadali w niedziele w godzinach 7-9, ale 4 marca 1940 roku Niemcy nakazali otwieranie kościoła nie wcześniej niż o godzinie 8 (od XI 1940 dopiero od godziny 8.30), co ograniczyło wiernym możliwość wyspowiadania się. W październiku 1940 roku Niemcy wyrazili zgodę na udzielanie sakramentu pokuty także w soboty (do godziny 19), ale mimo próśb odmówiono zgody na odprawienie dodatkowych nabożeństw w Boże Narodzenie ${ }^{28}$. We wprowadzanych zmianach widoczna była zła wola okupanta. Od stycznia do sierpnia 1940 roku duchowieństwo na Łazarzu zmuszone było przynajmniej trzykrotnie zmienić porządek nabożeństw w kościele. Informacje o tym nie zawsze docierały do wiernych na czas, co skutecznie wykluczało możliwość udziału w liturgii.

Kościół łazarski, choć duży, nie był w stanie pomieścić wiernych z połowy miasta i jego najbliższych okolic. Zakaz „zbiegowisk” pod kościołem w trakcie nabożeństw oraz obowiązek gromadzenia się w środku świątyni od początku był niemożliwy do spełnienia mimo ofiarności kościelnego (Józefa Rolnika) i marszałków parafialnych, starających się wprowadzić do kościoła przybyłych na nabożeństwo wiernych. Jesienią 1940 roku księża musieli przypomnieć parafianom o obowiązującym zakazie przebywania przed kościołem (apele te ponawiano wielokrotnie do 1943 roku). Zabiegano także, aby wierni nie pozostawali na kolejnej mszy św., co umożliwiało udział w Eucharystii innym parafianom ${ }^{29}$.

Wraz z rosnącymi trudnościami na frontach II wojny światowej po stronie Niemców dało się zauważyć dążenie do zmniejszenia restrykcji wobec

\footnotetext{
${ }^{27}$ Tamże, karta „1940 rok”, s. 1-6; karta „1941 rok”, s. 4.

${ }^{28}$ Tamże, karta „1940 rok”, s. 1-6.

${ }^{29}$ Tamże, karta „1940 rok”, s. 4; karta „1943 rok”, s. 1.
} 
Polaków, lecz mimo to 23 marca 1942 roku skonfiskowano parafii wszystkie dzwony, przeznaczając je na cele niemieckiego wysiłku wojennego. Miesiąc po zdemontowaniu ich $\mathrm{z}$ wieży kościelnej dzwony wywieziono $\mathrm{z}$ parafii ${ }^{30}$. W tym samym roku dało o sobie znać rosnące zagrożenie dla miasta ze strony alianckiego lotnictwa. Utrzymano w mocy wcześniejszy zakaz o odprawianiu mszy w dzień po ogłoszeniu alarmu przeciwlotniczego. Władze nakazały parafii wymianę bocznych drzwi wejściowych do kościoła na szersze, aby umożliwić ucieczkę wiernym w razie nalotu. Parafia zastosowała się do polecenia niemieckiego, wymieniając główne drzwi wejściowe w 1942 roku i boczne rok później (były to pierwsze od 1939 roku inwestycje w budynku kościoła; rok wcześniej przeprowadzono remont zegara na wieży kościelnej). Ponadto do końca pierwszego kwartału 1942 roku władze okupacyjne nakazały parafii utworzenie formacji przeciwpożarowej (złożonej ze 120 mężczyzn) i ewakuacyjnej (60 kobiet). Powołano je do końca kwietnia 1942 roku. W ślad za tym nakazano obu formacjom prowadzenie stałych ćwiczeń z zakresu ewakuacji ludzi (ćwiczenia prowadzono od 1943). Jednocześnie Niemcy wydali nowe zarządzenia na wypadek ataku lotniczego na Poznań ${ }^{31}$.

Wprawdzie niemieckie zarządzenia o obronie przeciwlotniczej brzmiały groźnie, ale poznaniacy nie traktowali ich poważnie. Front wciąż znajdował się daleko, choć wiedziano o niemieckich porażkach. Wciąż większy lęk budziła obecność Niemców na ulicach miasta niż trudna do wyobrażenia groźba bombardowania Poznania przez sojuszników z zachodu. Wprawdzie pierwszy nalot na miasto miał miejsce już 8/9 maja 1941 roku, ale nie zapisał się on trwale w pamięci polskich mieszkańców Poznania m.in. dlatego, że jego ofiarami byli głównie Niemcy, mieszkający w kamienicach przy ulicy Śniadeckich $^{32}$. Dopiero duży nalot na miasto, przeprowadzony 9 kwietnia 1944 roku przez brytyjskie i amerykańskie lotnictwo, unaoczniło Polakom grozę bombardowań lotniczych. Celem nalotu stał się teren Pewuki, gdzie Niemcy zlokalizowali zakłady produkcyjne Focke-Wulfa, fabryka amunicji na Dębcu i Dworzec Główny. Zniszczenia dotknęły również zabudowania cywilne w centrum i na obrzeżach miasta. Śmierć pod gruzami poniosły 82 osoby, w tym 47 Polaków, ponadto w wyniku ataku na dworzec kolejowy zginęło 150 żołnierzy

${ }^{30}$ AP MBB, M. Frankiewicz, Wspomnienia z lat okupacji, s. 18.

${ }^{31}$ AP MBB, Kronika parafii MB Bolesnej 1896-1958, cz. II (Suplement), karta „1942 rok”, s. 1-2. - Wspomniane ograniczenia nakazywały wiernym pozostanie w kościele Matki Boskiej Bolesnej, o ile nie zdążyli oni opuścić świątyni przed rozpoczęciem nalotu. Ponadto zakazano odprawiania pierwszej mszy porannej w dzień po ogłoszeniu alarmu przeciwlotniczego, o ile jego odwołanie nastąpiło po północy. Patrz także: AP MBB, Kronika parafii MB Bolesnej 1896-1958, cz. II (Suplement), karta „1944 rok”, s. 1.

32 Zbombardowanie Poznania w 1941 roku było najprawdopodobniej efektem błędu pilota brytyjskiego, który w trakcie lotu nad inny obiekt w Niemczech oderwał się od swojej eskadry i pomylił kierunki, przypadkowo znajdując się nad Poznaniem. 
niemieckich. Kolejny nalot miał miejsce 29 maja 1944 roku. Jego celem były ponownie zakłady Focke-Wulfa na terenie Pewuki oraz w Krzesinach, a także zakład produkcyjny niemieckiej firmy Telefunken przy ulicy Śniadeckich. Ofiarami nalotu padło 41 osób, w tym 25 Polaków $^{33}$. Wkrótce po pierwszym bombardowaniu władze niemieckie zgodziły się na zorganizowanie uroczystego pogrzebu polskim ofiarom bombardowań. W nabożeństwie uczestniczył internowany w parafii biskup Walenty Dymek. Mimo nacisków ze strony okupanta biskup odmówił zgody na propagandowe wykorzystanie jego udziału w pogrzebie ${ }^{34}$.

Wydarzenia na frontach II wojny światowej w 1943 roku sprawiły, że wierni z łazarskiej parafii z coraz większą śmiałością manifestowali swoje przywiązanie do wiary. Przepis dotyczący zakazu gromadzenia się przed kościołem w trakcie nabożeństw nie był respektowany, czego dowodzi konieczność wielokrotnego powtarzania go z ambony przez duchowych. Odwaga Polaków, a jednocześnie postępujące osłabienie III Rzeszy sprawiły, że urzędowe wytyczne oraz nakazy wobec wiernych z parafii były coraz bardziej groteskowe. W 1943 roku administracja okupacyjna krytykowała członków łazarskiej wspólnoty kościelnej za rzekome zanieczyszczanie ulicy Głogowskiej, rozrzucanie papierków i biletów tramwajowych. Zarzucono także wiernym, że udając się grupowo do kościoła, hamują ruch tramwajów ${ }^{35}$.

Nadzieje, jakie wiązano z rychłym zakończeniem II wojny światowej, uwidoczniły się w rosnącej pobożności i dużej frekwencji w nabożeństwach (co można też wiązać z obecnością w parafii od 1943 roku biskupa Walentego Dymka). Przejawem „nadziei” była też popularność listownego „łańcuszka szczęścia”, która ujawniła się jesienią 1943 roku, gdy rozpowszechniło się w parafii wzajemnie wysyłanie sobie listów. Zawierały one polecenie wielokrotnego przepisania listu i rozesłania znajomym pod groźbą życiowego nieszczęścia. Autor i adresat listu musieli ponadto wypełnić pewne zalecenia. Przeciw dalszemu szerzeniu „zabobonnego łańcuszka” wystąpił ks. Marian Frankiewicz i pozostali duchowni, uspokajając parafian oraz zachęcając ich do pobożnego wysiłku i dobrych uczynków. Przyniosło to zamierzony efekt, gdyż rok później listowny „łańcuszek szczęścia” wygasł. Niestety, trudne czasy wojny i problemy z nabyciem podstawowych dóbr pobudziły niektórych ludzi

${ }^{33}$ B. Rudawski, Alianckie naloty na Poznań, „Z Archiwum Instytutu Zachodniego”, nr 2, 2016: http://www.iz.poznan.pl/plik,pobierz, 1276,f1fc479f4ebf92e52d4fd4d4332953df/nr\%202\%20-\%20 2016\%20-\%20Z\%20Archiwum\%20Instytutu\%20Zachodniego.pdf [dostęp: 20.06.2017].

${ }^{34}$ L. Wilczyński, Ksiadz arcybiskup Walenty Dymek. Efekty inwigilacji, [w:] Ksiadz Arcybiskup Walenty Dymek, Metropolita Poznański (1888-1956), red. L. Wilczyński, Poznań 2010, s. 177-202; K. Białecki, Pod czujnym okiem bezpieki. Arcybiskup Walenty Dymek w materiałach WUBP w Poznaniu, [w:] Ksiądz Arcybiskup Walenty Dymek, Metropolita Poznański (1888-1956), red. L. Wilczyński, Poznań 2010, s. 203-234.

${ }^{35}$ AP MBB, Kronika parafii MB Bolesnej 1896-1958, cz. II (Suplement), karta „1943 rok”, s. 1. 
do kradzieży. Niecny proceder wzmógł się w 1943 roku, kiedy wielu parafian uczestniczących w niedzielnych nabożeństwach padło ofiarą kieszonkowców. Szczególnie dotkliwe były przypadki kradzieży kartek żywnościowych. Kradzieże w kościele, wśród rozmodlonych parafian, spowodowały szczególne oburzenie. Sprawców nie udało się ująć, księża zaś apelowali o większą uwagę, a przede wszystkim o pozostawianie w domu kosztowności ${ }^{36}$.

Mimo okupacyjnego rygoru prawnego i licznych utrudnień nie zaniedbywano życia sakramentalnego wiernych. Posługujący w parafii księża z trudem zaspokajali potrzeby duchowe parafian. Jak wspomniano wcześniej, przeszkodą w duszpasterstwie był też ograniczony czas pracy biura parafialnego, co szczególnie utrudniało narzeczonym załatwienie wszystkich formalności. Dla zapewnienia bezpieczeństwa wiernym zaprzestano prowadzenia tablicy z informacjami parafialnymi. Uroczystości ślubne odbywały się przy ograniczonej liczbie wiernych (tylko członkowie najbliższej rodziny). Znacznie trudniejsze było zorganizowanie Pierwszej Komunii Świętej dzieci.

Dla bezpieczeństwa nie informowano ogółu parafian o dacie Komunii, choć wyjątkowo dużą frekwencję dzieci w nabożeństwach niedzielnych trudno było ukryć. Po raz pierwszy w warunkach okupacyjnych Pierwszej Komunii udzielono dzieciom 28 lutego 1940 roku (msza o godz. 9). Wobec zamknięcia przez Niemców kościoła św. Michała 31 marca 1940 roku Pierwszej Komunii udzielono dzieciom $\mathrm{z}$ tej parafii. Wbrew tradycji dzieci nie podchodziły do ołtarza $\mathrm{w}$ grupie, ale indywidualnie wraz z pozostałymi wiernymi ${ }^{37}$. Wobec zamknięcia kościoła Świętego Krzyża na Górczynie rok później Pierwszej Komunii udzielono w tutejszej parafii aż trzykrotnie (20 IV, 18 VII i 20 XII) $)^{38}$. Co najmniej trzykrotnie udzielono Pierwszej Komunii dzieciom w 1942 roku (13 VI, 2 X, 14 XI). Prawdopodobnie ceremonia miała miejsce także 21 października (źródła parafialne są w tej sprawie nieprecyzyjne) ${ }^{39}$. W 1943 roku uroczystość Pierwszej Komunii zorganizowano w parafii pięciokrotnie: 8 i 16 V, 23 X oraz 13 XI (chłopcy) i 20 XI (dziewczęta). Bombardowanie Poznania w kwietniu i maju 1944 roku spowodowało zmianę terminu: chłopcy i dziewczęta przystąpiły do Stołu Pańskiego 1 lipca, a następnie 11 listopada (chłopcy), 18 listopada (dziewczęta) oraz 25 listopada (wszystkie dzieci) ${ }^{40}$.

Znacznemu ograniczeniu uległ ceremoniał pogrzebowy. W latach 1939-1941 był on objęty niemieckimi restrykcjami w niewielkim stopniu, choć

${ }^{36}$ Tamże, s. 4.

${ }^{37}$ Tamże, karta „1942 rok”, s. 2.

${ }^{38}$ W uroczystościach z 20 kwietnia 1941 roku uczestniczyło 74 chłopców i 40 dziewcząt. Frekwencja podczas dwóch następnych uroczystości nie jest znana. Patrz: AP MBB, Kronika parafii MB Bolesnej 1896-1958, cz. II (Suplement), karta „1941 rok”, s. 5.

${ }^{39}$ Tamże, karta „1942 rok”, s. 5.

${ }^{40}$ Tamże, karta „1944 rok”, s. 3-4. 
udział większej liczby osób w pogrzebach (,zbiegowisko”) hitlerowcy przyjmowali z niechęcią. Nabożeństwa pogrzebowe były jedynymi, jakie wolno było odprawiać w dni powszechnie. Dopiero z początkiem 1941 roku Niemcy ograniczyli liczbę osób uprawnionych do uczestnictwa w pogrzebie do najbliższej rodziny, nakazując przy tym, aby uroczystość celebrować przy drzwiach zamkniętych kościoła. W drugiej połowie 1941 roku Niemcy zakazali także udziału osób spoza kręgu rodzinnego w pochówku na Cmentarzu Górczyńskim $^{41}$.

Cmentarz należący do parafii został przejęty przez administrację okupacyjną w 1941 roku. W ten sposób parafię pozbawiono wpływów z opłat dzierżawnych, wierni zaś zmuszeni zostali do wypełniania dokumentacji urzędowej pod groźbą likwidacji grobowca rodzinnego. Pozbawienie parafii dochodów $\mathrm{z}$ dzierżaw cmentarnych nie było jedyną metodą finansowego niszczenia łazarskiej wspólnoty. W sposób nieoczekiwany hitlerowcy zabronili z dniem 1 kwietnia 1941 roku zbierania ofiar na tacę (ostatnie ofiary zebrano legalnie podczas mszy 23 i 30 III 1941). Wkrótce nakazano także usunięcie skarbon kościelnych lub zaspawanie otworów wrzutowych. Brak możliwości utrzymania się z dobrowolnych ofiar stanowił poważne zagrożenie dla dalszego funkcjonowania parafii na Łazarzu. Odpowiedzią księdza administratora Alfonsa Jankowskiego było przywrócenie taks parafialnych za dzierżawę ławek kościelnych ${ }^{42}$. Działania księdza administratora spotkały się z pełnym zrozumieniem ze strony parafian, którzy zresztą od pierwszych chwil okupacji ofiarnie wspierali parafię materialnie.

Podkreślić należy wyjątkowy wkład ks. Alfonsa Jankowskiego - po aresztowaniu proboszcza Józefa Gorgolewskiego (1940) faktycznego zarządcy parafii Matki Boskiej Bolesnej - w stworzenie podziemnego systemu dobroczynnego i utworzenie zaplecza finansowego parafii w warunkach okupacyjnej rzeczywistości. Ciesząc się dużym uznaniem i zaufaniem ze strony parafian, utworzył on - mimo zakazów - sprawny system pozyskiwania finansów dla dzieł dobroczynnych. Z przyczyn oczywistych (prowadzenie ksiąg parafialnych w ograniczonym zakresie z pominięciem personaliów ofiarodawców) trudno ustalić skalę wysiłków charytatywnych wiernych łazarskich, ale ze spisanych po II wojnie światowej wspomnień ks. Wacława Jesse wiadomo, że „parafia łazarska w czasie okupacji miała wielkie dochody, gdyż ludzie nie żałowali ofiar". W system ten zaangażowani byli wszyscy księża mieszkający na probostwie oraz współpracujący na jej rzecz w podziemiu. W dzieło dobroczynne zaangażowane były też siostry zakonne wspierające parafię. Pozyskiwane dobra - materialne i pieniężne - szybko dystrybuowano wśród

\footnotetext{
${ }^{41}$ Tamże, s. 1-5.

${ }^{42}$ Tamże, s. 2, 4.
} 
mieszkańców Poznania, wysyłano potrzebującym w Generalnym Gubernatorstwie oraz w niemieckich obozach pracy. Chęć pomocy bliźniemu była wśród parafian tak wielka, że przed 1943 rokiem wielokrotnie dochodziło do spontanicznych i organizowanych oddolnie zbiórek na rzecz potrzebujących. Inicjatywom tym nie towarzyszył właściwy poziom dyskrecji. Aby nie narażać wiernych na ryzyko niemieckich represji, administrator Alfons Jankowski zaapelował o zaprzestanie podobnych praktyk ${ }^{43}$.

Trudno dokładnie ustalić liczbę księży, którzy w czasie okupacji niemieckiej sprawowali posługę kapłańską w parafii Matki Boskiej Bolesnej, choć niepotwierdzone źródła parafialne mówią, że nawet o 40 duchownych w latach 1939-1945 ${ }^{44}$. Spośród przedwojennej obsady duszpasterskiej był wikariusz Edmund Lorkiewicz (1907-1981), którego aresztowano 12 grudnia 1939 roku i osadzono w Kazimierzu Biskupim. Uzyskał zwolnienie z obozu i 5 czerwca 1940 roku udał się do Generalnego Gubernatorstwa, skąd powrócił do archidiecezji poznańskiej dopiero po jej wyzwoleniu w 1945 roku $^{45}$. Tragiczny los spotkał proboszcza Józefa Gorgolewskiego (1889-1942). Aresztowano go 20 kwietnia 1940 roku i trzykrotnie przewożono do obozów koncentracyjnych (Dachau, następnie Gusen i ponownie Dachau). Zmarł w 1942 roku (data jego śmierci i okoliczności nie są do końca znane ${ }^{46}$. Wikariusz Roman Hildebrand (1908-1972) został aresztowany 15 sierpnia 1940 roku i osadzony początkowo w poznańskim Forcie VII, następnie w Buchenwaldzie i Dachau, gdzie poddawano go m.in. eksperymentom pseudomedycznym. Doczekał wyzwolenia obozu, a po powrocie do archidiecezji został proboszczem parafii w Mosinie ${ }^{47}$. Od chwili aresztowania ostatniego z wymienionych duchownych obowiązki kapłańskie sprawowali w parafii oficjalnie już tylko administrator Alfons Jankowski i wikariusz Marian Frankiewicz.

Ksiądz Alfons Jankowski (1907-1943) cieszył się dużym uznaniem i szacunkiem wiernych. Sprawnie zorganizował opiekę duszpasterską nad większą częścią miasta, która podlegała wówczas parafii na Łazarzu. Zawsze z uwa-

${ }^{43}$ W. Jesse, Wspomnienia pośmiertne. Ksiądz Alfons Jankowski. Jednodniówka, Poznań 1948, s. $14-15$.

${ }^{44}$ Ł. Jastrząb, Życie religijne w Poznaniu podczas okupacji niemieckiej (1939-1945). Część II, „Poznańskie Zeszyty Humanistyczne”, t. XXV, 2016, s. 51.

45 M. Banaszak, Edmund Lorkiewicz (1907-1981), [w:] Duchowieństwo archidiecezji poznańskiej. Kapłani zmarli w latach 1946-2014, red. L. Wilczyński, Poznań 2014, s. 555-557.

46 J. Kozłowski, Józef Gorgolewski (1889-1942), [w:] Księża społecznicy w Wielkopolsce 1894-1919, t. I, red. M. Banaszak, Gniezno 1992, s. 232-233.

47 W. Joachimczak, Roman Hildebrandt (1908-1972), [w:] Duchowieństwo archidiecezji poznańskiej. Kaplani zmarli w latach 1946-2014, red. L. Wilczyński, Poznań 2014, s. 306-307; E. Majka, Pracowali w tej parafii..., „Wiadomości Parafialne Parafii Mosińskiej”, nr 146, 2013, s. 1; K. Śmigiel, Losy Kościola katolickiego w okupowanym Poznaniu, KMP, nr 3, 2009, wydanie internetowe: https://wbc.macbre.net/document/6909/losy-kosciola-katolickiego-w-okupowanym-poz naniu-ks-kazimierz-smigiel.html [dostęp: 21.06.2017]. 
gą słuchał rozmówców, daleki od uprzedzeń, słynący z dowcipu i humoru, którymi rozładowywał złe emocje szczególnie po 1939 roku $^{48}$. Wiadomo, że zaangażowany był w działalność podziemia. Służył w Armii Krajowej jako kapelan obwodu Poznań-Łazarz ${ }^{49}$. Ten fakt, podobnie jak niestosownie się do niemieckich zarządzeń (udzielenie ślubu mimo braku zgody administracji niemieckiej), a także utrzymywanie kontaktu z Polakami w Generalnej Guberni spowodowały, że został aresztowany przez Gestapo 29 października 1943 roku. Osadzono go w Forcie VII, gdzie był przesłuchiwany i poddawany okrutnym torturom. Zmarł zamęczony 17 listopada 1943 roku $^{50}$.

Wraz ze śmiercią ks. Alfonsa Jankowskiego obowiązki administratora przejął ks. Marian Frankiewicz (1907-1986). W chwili wybuchu II wojny sprawował obowiązki kapelana Polskiego Czerwonego Krzyża. Udał się pieszo wraz z grupą uciekinierów do Warszawy, ale szybkie zajęcie Wielkopolski przez Niemców odcięło drogę ucieczki do stolicy. Spod wielkopolskiej Słupcy - ponownie pieszo - wrócił do Poznania, udając się do matki, mieszkającej przy ulicy Małeckiego. Niezwłocznie zgłosił się z pomocą w rodzinnej parafii Matki Boskiej Bolesnej. Mianowany wikariuszem substytutem podjął obowiązki duszpasterskie, szybko zyskując sympatię i zaufanie parafian. Mimo krótkiego stażu kapłańskiego (święcenia 14 VI 1930) umiejętnie radził sobie $\mathrm{z}$ kierowaniem rozległą parafią łazarską $\mathrm{w}$ warunkach okupacji. Z pewnością nie bez znaczenia była pomoc i wsparcie ze strony przebywającego od stycznia 1943 roku w areszcie domowym biskupa Walentego Dymka. Brak informacji świadczących o zaangażowaniu ks. Mariana Frankiewicza w działalność podziemną, ale już sama znajomość z ks. Alfonsem Jankowskim czyniła zeń podejrzanego w oczach Niemców. $Z$ tego też powodu był wielokrotnie wzywany na Gestapo. Główny zarzut, który mu stawiano, polegał na słuchaniu spowiedzi poza wyznaczonym przez Niemców czasem. Jego sprawa trafiła aż do Berlina, ale na szczęście część archiwum niemieckiej policji politycznej została zniszczona w wyniku bombardowań stolicy III Rzeszy. Dochodzenie przeciwko niemu z czasem zawieszono ${ }^{51}$. Ksiądz Marian Frankiewicz jako jedyny z posługujących w czasie okupacji - pozostał w parafii do końca II wojny światowej. Po jej zakończeniu był proboszczem parafii do 1982 roku.

Warunki życia okupacyjnego przyczyniły się do umocnienia więzi między mieszkańcami probostwa łazarskiego. Pierwsze piętro budynku zajmował

${ }^{48}$ W. Jesse, Wspomnienia pośmiertne, s. 3-7.

49 J. Piętka, Alfons Jankowski (1907-1943), http:/www.wtg-gniazdo.org/ksieza/main. php?akcja=opis\&id=1530 [dostęp: 22.06.2017].

${ }^{50}$ AP MBB, Kronika parafii MB Bolesnej 1896-1958, cz. II (Suplement), Nekrolog księdza Alfonsa Jankowskiego.

${ }^{51}$ AP MBB, Materiały do Kroniki. Teczka I. Ankieta dotycząca losów duchowieństwa, ankieta księdza Mariana Frankiewicza (1974), mps, s. 3. 
proboszcz Józef Gorgolewski. Na drugim piętrze mieli skromne mieszkania ks. Alfons Jankowski i pozostali duchowni. Wikariusz Marian Frankiewicz mieszkał z matką przy ulicy Małeckiego. W budynku mieszkali także: Katarzyna Horowska (gospodyni) i Józef Rolnik (kościelny). Sytuacja ta zaczęła się zmieniać wraz z aresztowaniami domowników. Po aresztowaniu przez Gestapo proboszcza Józefa Gorgolewskiego (24 IV 1940) opiekę nad jego mieszkaniem przejął ksiądz administrator Alfons Jankowski. Nie trwało to długo, gdyż jeszcze w tym samym roku władze okupacyjne zakwaterowały na probostwie oficera Gestapo Franza Wolfa wraz z żoną i dwiema córkami.

Niewiele wiadomo o niechcianym niemieckim lokatorze probostwa łazarskiego. Z pewnością był katolikiem, gdyż po jego ucieczce z Poznania w 1945 roku znaleziono wśród pozostawionych rzeczy pamiątkę Pierwszej Komunii jednej z córek. Zajmując mieszkanie po proboszczu, gestapowiec urządził je meblami pochodzącym z kradzieży. Na własne potrzeby zarekwirował też część mebli parafialnych. Jego obecność budziła strach. Domagał się uległości i okazywania mu szacunku. Rzadko pojawiał się w pozostałych mieszkaniach probostwa i w biurze parafialnym ${ }^{52}$. Nie było to potrzebne do skutecznego inwigilowania domowników, gdyż w ścianach mieszkania zajmowanego przez rodzinę Wolfów umieszczono instalację podsłuchową, której istnienie odkryto podczas remontu probostwa w 1995 roku $^{53}$.

Niebezpieczeństwo wynikające z obecności rodziny Wolfów na plebanii wzrosło, gdy w styczniu 1943 roku władze okupacyjne zakwaterowały na probostwie poddanego rygorom aresztu domowego biskupa Walentego Dymka. Obecność na Łazarzu jedynego przedstawiciela władz kościelnych archidiecezji sprawiła, że probostwo stało się miejscem wizyt ukrywającego się duchowieństwa. Wielokrotnie dochodziło do przypadkowych spotkań księży z gestapowcem Franzem Wolfem lub jego konfidentami. Przypadki takie opisał w swych wspomnieniach ks. Marian Frankiewicz. Proboszcz parafii w Rożnowie, ks. Adam Schmidt, tylko własnemu refleksowi zawdzięczał uniknięcie aresztowania. Spotkany przypadkowo przez gestapowca w biurze parafialnym i spytany o personalia i wykonywany zawód przedstawił się i odparł, że jest kelnerem, co uwiarygodniła „prezencja” duchownego. Spostrzegawczości zawdzięczał zachowanie wolności poszukiwany przez Niemców ks. Hieronim Lewandowski, którego po jednej z wizyt u biskupa Walentego Dymka odprowadzał ulicą Chłodną ks. Marian Frankiewicz. Nagle oczom obu duchownych ukazał się idący z naprzeciwka Franz Wolf. Ksiądz Hieronim Lewandowski gwałtownie uskoczył w bok, ku jednej z kamienic, kryjąc się na jej podwórzu.

${ }^{52}$ AP MBB, M. Frankiewicz, Wspomnienia z lat okupacji, s. 15-16.

${ }^{53}$ Zbiory własne autora, L. Wilczyński, Historia parafii Matki Boskiej Bolesnej w Poznaniu, mps. 
Reakcja poszukiwanego przez okupantów kapłana była tak szybka, że ledwo spostrzegł ją ks. Marian Frankiewicz, zaś gestapowiec nie zdążył niczego zauważyć ${ }^{4}$.

Ze względu na obecność niemieckiego funkcjonariusza rozmowy prowadzono między sobą po cichu, a najczęściej poza budynkiem probostwa. Nie stanowiło to jednak żadnego zabezpieczenia, gdyż probostwo odwiedzali także donosiciele niemieckiej policji. Częstym gościem gestapowca był wspomniany już konfident Faelsch. Ksiądz Marian Frankiewicz wspominał po latach, że był świadkiem, jak Faelsch wraz z Franzem Wolfem z trudem przynieśli kiedyś na probostwo ciężką skrzynię $\mathrm{z}$ różnymi zrabowanymi przedmiotami ${ }^{55}$.

Trudno ustalić rolę Franza Wolffa w aresztowaniu ks. Alfonsa Jankowskiego, ale jako funkcjonariusz zaangażowany w prześladowanie Kościoła katolickiego w tzw. Kraju Warty dysponował rozległą wiedzą o działaniach wymierzonych w łazarskiego administratora. Mimo to umożliwił on kościelnemu, Józefowi Rolnikowi, dostarczenie aresztowanemu kapłanowi żywności i odzieży ${ }^{56}$. Obecność niemieckiej rodziny na probostwie stanowiła duże zagrożenie dla wszystkich jego domowników. Nie oznaczało to jednak, by byli oni całkowicie bezbronni i bezradni. Inwigilowano rodzinę Wolfów, przeglądając ich rzeczy osobiste, dokumenty i notatki gestapowca, o ile były pozostawione w dostępnym miejscu. Te dyskretne działania prowadziła s. Władysława Zakrzewicz, szarytka pomagająca przy parafii.

$\mathrm{Z}$ chwilą zamieszkania na probostwie łazarskim biskupa Walentego Dymka życie towarzyskie ożywiło się. Wobec zakazu pojawiania się biskupa w kościele i uczestnictwa w mszach jedno z pomieszczeń budynku przekształcono w jego prywatną kaplicę. Obecność biskupa dodawała otuchy domownikom, a plebania stała się miejscem odwiedzanym przez wielu księży. Bez wątpienia na probostwie dochodziło do spotkań biskupa pomocniczego z emisariuszami rządu londyńskiego i przedstawicielami metropolity krakowskiego, na ręce którego biskup Walenty Dymek wysyłał sprawozdania o sytuacji Kościoła na ziemiach wcielonych do III Rzeszy (sprawozdania abp Adam Sapieha przekazywał do Stolicy Apostolskiej). Częstym gościem internowanego biskupa był ks. Józef Nowacki, zawsze zagajający spotkania tematem de politicis ${ }^{57}$.

Osadzony w areszcie domowym na Łazarzu biskup miał zakaz opuszczania probostwa i uczestnictwa w życiu religijnym parafii, co często ignorował. Widywano go spacerującego ulicami dzielnicy, przez pewien czas udzielał się także w życiu łazarskiej wspólnoty kościelnej. Wprawdzie nigdy nie odprawił

\footnotetext{
${ }^{54}$ Tamże, s. 17.

55 Tamże, s. 15.

${ }^{56} \mathrm{~W}$. Jesse, Wspomnienia pośmiertne, s. 13.

${ }^{57}$ Tamże, s. 16.
} 
nabożeństwa, ale wiadomo, że spowiadał wiernych, którzy opowiadali o tym wśród krewnych i znajomych.

Gadulstwo ludzi było poważnym zagrożeniem dla bezpieczeństwa wspólnoty łazarskiej. Wielokrotnie przestrzegał przez tym ks. Alfons Jankowski („Uważajmy na swój język, aby nie mówić tego, czego nie potrzeba. Obleczmy się w milczenie, idźmy za cierpiącym Zbawicielem"58). Aby nie prowokować wiernych do plotkowania, biskup Walenty Dymek z czasem zaprzestał spowiadania, co skomplikowało i tak niełatwe położenie parafian ${ }^{59}$.

W 1943 roku, wraz z klęską III Rzeszy pod Stalingradem, sytuacja katolików w Poznaniu zaczęła się nieznacznie poprawiać. Także Polacy wykazywali się coraz większą odwagą. W parafii zaczęto organizować słuchanie spowiedzi poza wyznaczonymi przez Niemców godzinami, co czyniono w ukryciu. Spowiedzi słuchano w zakrystii, do której kościelny dyskretnie wprowadzał grupę kilkudziesięciu osób. Po wysłuchaniu wszystkich i udzieleniu rozgrzeszenia kościelny wyprowadzał penitentów do świątyni (lub poza kościół) w mniejszych grupach, by nie zwracali na siebie uwagi. Innym sposobem było zamknięcie w kościele grupy parafian - po ostatniej dopuszczalnej danego dnia mszy - wyspowiadanie ich i wypuszczenie z kościoła przed godziną policyjną $^{60}$. O lekceważeniu nakazów niemieckich świadczyło także powtarzanie $\mathrm{z}$ ambony zakazu gromadzenia się przed kościołem, co często okazywało się bezskuteczne $(1943)^{61}$.

Wielkiej dyskrecji i zachowania tajemnicy wymagały starania podejmowane przez parafię na rzecz podtrzymania życia kulturalnego, co było przez okupanta niemieckiego surowo zakazane. Mimo to w październiku 1939 roku reaktywowano chór kościelny, którym przed wybuchem II wojny światowej kierował prof. Witalis Dorożała, a organistą był Stanisław Szukalski. W listopadzie 1939 roku kierowanie chórem przejął Edward Serwański, absolwent poznańskiego Konserwatorium Muzycznego. Wprawdzie administracja niemiecka zakazała śpiewu kościelnego, ale w łazarskiej parafii nie zaniechano tradycji pięknej oprawy liturgicznej. Wysiłki parafian wspierał początkowo proboszcz Józef Gorgolewski, a po jego aresztowaniu księża: Alfons Jankowski i Marian Frankiewicz.

Ze względu na przymus wielogodzinnej pracy i zmęczenie, a także zakaz gromadzenia się ludności polskiej występy chóru kościelnego odbywały się na ogół bez wcześniejszych prób. Ich zorganizowanie w kościele, a tym

\footnotetext{
${ }^{58}$ AP MBB, Kronika parafii MB Bolesnej 1896-1958, cz. II (Suplement), karta „1943 rok”, s. 1.

${ }^{59}$ M. Banaszak, Walenty Dymek, [w:] Księża społecznicy w Wielkopolsce 1894-1919, t. I, red. M. Banaszak, Gniezno 1992, s. 165.

${ }^{60}$ AP MBB, Materiały do Kroniki. Teczka I. Ankieta dotycząca losów duchowieństwa, ankieta księdza Mariana Frankiewicza (1974), s. 3.

${ }^{61}$ C. Epstein, Wzorcowy nazista, s. 287-290.
} 
bardziej w domach prywatnych natychmiast zwróciłyby uwagę niemieckiej policji i Gestapo, czego starano się unikać. Śpiew chóralny pozbawiony był także oprawy muzycznej w wykonaniu orkiestry. Występom towarzyszyły tylko kościelne organy. W wielkiej tajemnicy przystąpiono zatem do organizacji chóralno-orkiestrowego koncertu wielkanocnego w 1940 roku. Trudno ustalić szczegóły tego przedsięwzięcia (liczba chórzystów, skład orkiestry), podobnie jak przygotowania do zorganizowanego rok później koncertu z okazji Zielonych Świąt. Źródła parafialne podają, że było to wielkie przeżycie artystyczne dla tłumnie przybyłych wiernych. Wśród słuchaczy szczególnie podniosłe emocje wzbudziło donośne Alleluja, a z oczu wielu parafian ciekły łzy wzruszenia i szczęścia ${ }^{62}$.

Rozbudzone w ten sposób przeżycia artystyczne mieszkańców Łazarza, Górczyna oraz innych dzielnic Poznania trudno było zaspokoić. Z zapisów parafialnych wynika, że w 1942 roku po raz kolejny - przy okazji Zielonych Świąt - odbył się w kościele występ chóru wraz z orkiestrą. Pięknym, tenorowym głosem zaśpiewał wówczas młody student Konserwatorium poznańskiego - Stefan Stuligrosz (1920-2012).

Wobec wyraźnego przeciwdziałania Niemców, a także coraz większych doświadczeń organizacyjnych i rosnącej śmiałości ludności polskiej w 1943 roku postanowiono zorganizować jeszcze większy koncert. Trudno ustalić pomysłodawcę inicjatywy, ale wiadomo, że w programie uroczystości znalazła się Msza Koronacyjna Wolfganga Amadeusza Mozarta i Kantata zielonoświatkowa Jana Sebastiana Bacha. Oznaczało to konieczność zorganizowania zespołu muzycznego, złożonego z ośmiu skrzypków, po dwóch wiolonczelistów i waltornistów, tyleż samo osób grających na obojach i jednej na kotłach. Niezbędne było zaangażowanie organisty (prof. Gertrudy Konatkowskiej). Planowano, że zespół muzyczny liczyć będzie razem 16 osób, a w chórze wystąpi 14 śpiewaków. Do przedsięwzięcia należało pozyskać osoby o wysokich zdolnościach wokalnych spoza chóru parafialnego, niezbędne było również pozyskanie nut oraz tekstów pieśni ${ }^{63}$.

Wielkim orędownikiem zorganizowania koncertu w 1943 roku był Stefan Stuligrosz, który zaoferował swoją pomoc przy kompletowaniu orkiestry i chóru. Przygotowanie uroczystości było niezwykle trudne. Wspomniane już zapisy nutowe i teksty pieśni dostępne były tylko w księgarniach nur für Deutsche (,tylko dla Niemców”), a zatem polscy klienci nie mogli ich legalnie na-

${ }^{62}$ AP MBB, Materiały do Kroniki. Teczka I, Notatki z rozmowy z dr. Edwardem Serwańskim, odbyta w dniach 20 i 23 lipca 1965 roku. Dokument jest kserokopią z zasobów Instytut Zachodniego, sygn. DOK III - 132, s. 1-4.

${ }^{63}$ Ostatecznie liczba osób uczestniczących w koncercie zielonoświątkowym w 1943 roku wyniosła: 16 osób w orkiestrze, 4 solistów wokalnych oraz 30-osobowy zespół Stuligrosza. Tamże, s. 5. 
być. Mimo tego niezbędne wydawnictwa pozyskano dzięki pomocy Polaków zatrudnionych w księgarniach i składach książek. O wiele bardziej skomplikowane było przeprowadzenie prób koncertowych i chóralnych. Zorganizowanie wspólnej, dużej próby całego zespołu wraz z chórem nie było możliwe. Prowadzono je zatem w większości w sposób cząstkowy w mieszkaniach prywatnych, ale wynajęto do tego celu także dom pogrzebowy, znajdujący się na zapleczu przedwojennego Konserwatorium Muzycznego w Poznaniu, przy ulicy Święty Marcin 87. W trakcie trwania prób okolice budynku patrolował dozorca, którego zadaniem było poinformowanie, czy słyszalna na zewnątrz muzyka nie wzbudza zainteresowania. $\mathrm{Na}$ szczęście nie było zagrożenia i po zakończonej próbie dozorca pomógł muzykom w opuszczeniu budynku w mniejszych grupach, by nie zwracali na siebie uwagi.

Wydawało się, że wszystko udało się utrzymać w tajemnicy. Wierni zgodnie z tradycją poprzednich lat okupacji - przygotowani byli na miłą niespodziankę, ale $\mathrm{z}$ pewnością nie $\mathrm{w}$ takiej formie. Tymczasem $\mathrm{w}$ dniu koncertu na chórze zjawili się wszyscy chórzyści i członkowie orkiestry. Na krótko przed rozpoczęciem pierwszej mszy św. na chór wszedł żołnierz Wehrmachtu, trzymając w ręce skrzypce. Przedstawił się zebranym jako skrzypek Filharmonii Wiedeńskiej. Obecność skrzypka przyjęto z lękiem, spodziewając się, że kościół jest otoczony przez wojsko i policję niemiecką, a zgromadzonych w świątyni czeka sroga kara ze strony Niemców. Obawy rychło okazały się bezzasadne, a żołnierz oświadczył, że chętnie weźmie udział w koncercie, którego program jest mu dobrze znany. Aby wzbudzić zaufanie kierującego chórem Edwarda Serwańskiego, żołnierz-skrzypek opowiedział po cichu kilka dowcipów na temat Adolfa Hitlera, zapewniając też, że nie jest nazistą. Postanowiono zaryzykować i powierzono muzykowi z Wiednia rolę pierwszego skrzypka. Decyzja okazała się wyjątkowo trafna, bo skrzypek był utalentowanym muzykiem. Według wspomnień Edwarda Serwańskiego niemiecki żołnierz: „okazał się skrzypkiem wręcz znakomitym. Grał po mistrzowsku i z pełnym wyczuciem. Ogromnie się bałem, jak wypadnie zharmonizowanie całej partii skrzypcowej. Niemiec jednak bardzo rygorystycznie poddawał się mojej dyrygenturze". Nie tylko dyrygent był pod wielkim wrażeniem umiejętności Austriaka, ale również prof. Gertruda Konatkowska, która tak bardzo wsłuchała się w jego grę, że nieomal spóźniła się z swoim fragmentem organowym ${ }^{64}$.

Koncert wielkanocny 1943 roku zrobił na parafianach łazarskich wielkie wrażenie. Po jego zakończeniu organizatorzy przystąpili do wyjaśniania okoliczności pojawienia się żołnierza Wehrmachtu. Co prawda przygotowania objęte były ścisłą tajemnicą, ale można przypuszczać, że dyskrecji nie dochowali

64 Tamże, s. 8. 
chórzyści i muzycy zaangażowani w przygotowania. Rychło okazało się to fałszywym tropem, gdyż Austriak zakwaterowany był w mieszkaniu polskiej rodziny, gdzie poznał Polkę, krewniaczkę członka koncertującego zespołu. Wiadomo, że młodzi zakochali się w sobie. Antynazistowska postawa Austriaka nie budziła wątpliwości, ale mimo to nie wtajemniczano go w życie łazarskiej wspólnoty. Całkiem przypadkowo, z nie dość dyskretnie prowadzonych w polskim domu rozmów, Austriak dowiedział się o koncercie i zapragnął w nim uczestniczyć. Polska rodzina próbowała odwieść go od karkołomnego pomysłu, ale nie przyniosło to skutku, a godzina policyjna uniemożliwiła poinformowanie o zagrożeniu organizatorów koncertu ${ }^{65}$.

Żywy udział wiernych w koncertach oraz ich powodzenie w latach 1940-1943 sprawiły, że z podobną inicjatywą wystąpiono także z okazji Zielonych Świąt w 1944 roku. Niestety, brak dokładniejszych informacji na temat tego koncertu. Można przypuszczać, że ze względu na napiętą sytuację polityczną, a przede wszystkim wojskową (gwałtowne zbliżanie się frontu wschodniego do granic III Rzeszy) miał on dużo skromniejszy charakter niż w 1943 roku.

Wyzwolenia spod niemieckiej okupacji oczekiwano w parafii z wielkim niepokojem, ale także z nadzieją. Rosły one stopniowo od 1943 roku, ale dopiero większe porażki Niemców na wszystkich frontach II wojny światowej w 1944 roku sprawiły, że koniec wojny stawał się coraz bliższy. Kończąc ostatnie nabożeństwo niedzielne 31 grudnia 1944 roku, ks. Marian Frankiewicz udzielił wiernym błogosławieństwa, polecając ich Bożej opatrzności i prosząc o gorliwą modlitwę w nadchodzącym roku ${ }^{66}$. Uczucie zbliżającego się przełomu było na Łazarzu powszechne. Wyczekiwano radzieckiej ofensywy, choć słabnąca niemiecka propaganda nadal głosiła wiarę w ostateczne zwycięstwo III Rzeszy nad wszystkimi jej wrogami. Spodziewany atak Armii Czerwonej nastąpił znad linii Wisły 12 stycznia 1945 roku. Pięć dni później Rosjanie wypędzili z ruin Warszawy ostatnie formacje niemieckie, natomiast 19 stycznia 1945 roku zajęto Łódź i Kraków. Kolejnym celem wojsk radzieckich stał się Poznań, ogłoszony w tym czasie twierdzą. Wprawdzie Niemcy nadal wypowiadali buńczuczne zapowiedzi, że to właśnie u wrót Poznania rozbije się radzieckie natarcie, ale nikt w te deklaracje nie wierzył. Dość powszechnie obawiano się wybuchu paniki wśród Niemców, która mogłaby sprowokować okupantów do ostatnich aktów bestialstwa i ślepego rewanżu. Księża parafii łazarskiej apelowali więc do wiernych przede wszystkim o zachowanie spokoju i powściągliwość.

Już od drugiej połowy stycznia 1945 roku ulicą Głogowską ciągnęły ku południowemu wylotowi z miasta tabory uciekinierów niemieckich ze wschod-

65 Tamże, s. 9.

66 Tamże, s. 5. 
nich obszarów tzw. Kraju Warty i z Generalnego Gubernatorstwa. Dopiero w sobotę 20 stycznia 1945 roku gauleiter Arthur Greiser wydał spóźniony rozkaz ewakuacji ludności niemieckiej z całego okręgu. Prawdopodobnie tego właśnie dnia doszło do masowej ewakuacji niemieckich mieszkańców Łazarza, co w kronice parafialnej (bez daty dziennej) zapisał ks. Marian Frankiewicz. Uciekinierzy do późnego wieczoru, mimo siarczystego mrozu, czekali na środku Rynku Łazarskiego na transport. Nazajutrz, w niedzielny poranek 21 stycznia 1945 roku po Niemcach nie było już śladu, a dzielnica ponownie była polska ${ }^{67}$.

Nie oznaczało to jednak spokoju ani bezpieczeństwa. Bardzo szybko wśród poznaniaków rozpowszechniła się plotka, że Niemcy zamierzają wypędzić z miasta wszystkich jego rdzennych mieszkańców. Z uwagi na los cywilnej ludności stolicy okupowanej Polski po powstaniu warszawskim pogłoska ta wydawała się całkiem wiarygodna. Mówiono powszechnie o samosądach, jakich dopuszczali się rzekomo uciekający Niemcy, o pompowaniu benzyny do kamienicznych piwnic, w których chronili się Polacy, i podpalaniu ich. Wiadomości te okazały się fałszywe, ale świadczyły o nerwowej atmosferze w mieście i strachu wśród mieszkańców. Atmosferę tę starali się uspokajać łazarscy duchowni, ale oni również lękali się o przyszłość.

W ostatnich dniach okupacji niemieckiej na probostwie nadal zakwaterowany był Franz Wolf z żoną i córkami. Do ostatnich chwil wizyty składali mu funkcjonariusze nazistowskiego reżimu i konfidenci Gestapo, powodując strach u mieszkańców. Ze względu na wydany rozkaz (prawda, że powszechnie ignorowany przez funkcjonariuszy NSDAP) urzędnicy niemieccy mieli wyjechać z tzw. Kraj Warty jako ostatni. Dzień przed opuszczeniem probostwa, co nastąpiło najpóźniej 23 stycznia 1945 roku, gestapowiec nakazał jego domownikom wydanie zapasów ze spiżarni, po czym zmożony alkoholem poszedł spać. Rankiem następnego dnia Franz Wolf rozkazał kościelnemu odwieźć się na dworzec kolejowy. Tam Józef Rolnik był świadkiem tego, jak w atmosferze paniki i poczucia klęski upadają autorytety. Wpływowy dotąd gestapowiec, jak tysiące pozostałych uciekinierów niemieckich z „,wzorcowego Gau”, musiał cierpliwie czekać w kolejce do pociągu ewakuacyjnego.

Wyjazd gestapowca z rodziną był symbolicznym końcem okupacji niemieckiej w łazarskiej parafii. Nadal oczekiwano przybycia Rosjan, obawiano się też zniszczeń spowodowanych oporem niemieckiej załogi miasta. Kronika parafialna potwierdza napiętą atmosferę w parafii i na probostwie na przełomie stycznia i lutego 1945 roku. Stwierdza ona, że pierwsze odgłosy bliskich strzałów artyleryjskich usłyszano w parafii 22 stycznia 1945 roku. Słychać je było od strony Dębca i Górczyna. Dla bezpieczeństwa wszyscy domownicy

${ }^{67}$ AP MBB, M. Frankiewicz, Wspomnienia z lat okupacji, s. 41. 
przenieśli się z parteru i obu pięter do piwnicy, gdzie spędzono następne dnie i noce. Nie wiadomo, aby w ostatnią styczniową niedzielę oraz lutowe niedziele odprawiono nabożeństwa, ale z pewnością - pomimo zagrożenia - duszpasterze parafialni wraz biskupem Walentym Dymkiem utrzymywali stały kontakt $\mathrm{z}$ duchownymi przebywającymi w ukryciu oraz parafiami. Emisariuszką była $\mathrm{w}$ tym czasie $\mathrm{s}$. Władysława Zakrzewicz, która $\mathrm{z}$ narażeniem własnego zdrowia i życia przemierzała ciemne i opustoszałe ulice miasta, przekazując i zbierając wiadomości ${ }^{68}$.

W ostatnich dniach stycznia 1945 roku na probostwo przychodzili parafianie poszukujący wsparcia duchowego. Nierzadko nachodzili domowników probostwa także niemieccy maruderzy. Tych ostatnich obawiano się najbardziej. Ciekawość budzili natomiast żołnierze radzieckiej forpoczty. Według kroniki parafialnej 27 stycznia 1945 roku od strony Górczyna weszli na Łazarz żołnierze regularnych oddziałów Armii Czerwonej. Pojawili się oni również na probostwie łazarskim, przynosząc jego mieszkańcom ostateczne wyzwolenie spod niemieckiej okupacji. Wkrótce wokół kościoła stanęły radzieckie kolumny zmotoryzowane, tabory konne i oddziały wojskowe, co nie uszło uwadze Niemców, broniących się na Cytadeli. Celem ich artylerii stał się kościół, ostrzelany - według kroniki parafialnej - w ostatnich dniach stycznia 1945 roku. Zapisy w kronice nie stwierdzają co prawda, z której strony kościoła spadły pociski, ale można przypuszczać, że uderzyły one na teren po stronie ulicy Stablewskiego, powodując znaczne uszkodzenia w nawie południowej świątyni (duże odpryski w ścianie, zniszczenie witraży). Zniszczenia nastąpiły także w nawie północnej (uszkodzenie gzymsu). Nie wiadomo nic o ofiarach śmiertelnych tego ostrzału, choć kronika parafialna stwierdza straty w taborze Armii Czerwonej (kilka koni) ${ }^{69}$.

Ostrzał kościoła na Łazarzu był sygnałem dla Rosjan, że dalsze stacjonowanie w jego okolicy stanowi dla wojsk radzieckich poważne zagrożenie. Rychło podjęto decyzję o wycofaniu jednostek z okolicy świątyni, co być może zapobiegło dalszemu ostrzałowi i większym zniszczeniom kościoła. Walki o miasto trwały jednak dalej i wkrótce trawniki wokół kościoła zamieniono na tymczasowy cmentarz żołnierzy radzieckich. Trudno dokładnie ustalić, ilu czerwonoarmistów pochowano wokół kościoła, ale kronika parafialna stwierdza, że mogił „szybko przybywało”. Duchowieństwo zaangażowane było również w pogrzeby mieszkańców Łazarza i Górczyna, którzy ponieśli śmierć w trakcie walk o Poznań. Archiwum kościelne stwierdza przynajmniej 28 zgonów parafian pochowanych na Cmentarzu Górczyńskim ${ }^{70}$.

${ }^{68}$ Tamże.

${ }^{69}$ Tamże, s. 44.

${ }^{70}$ L. Krajkowski, Zabytkowy cmentarz górczyński parafi Matki Boskiej w Poznaniu 1910-2010, Poznań 2010, s. 24. - Po zakończeniu działań wojennych w Poznaniu ciała zabitych żołnierzy 
Wprawdzie ostateczna kapitulacja niemieckiego garnizonu nastąpiła 23 lutego 1945 roku, ale już w z początkiem lutego 1945 roku mieszkający na łazarskim probostwie biskup Walenty Dymek przystąpił do odbudowy struktur kościelnych w archidiecezji poznańskiej. Wobec zniszczenia katedry, znacznych szkód w budynkach kurii i w innych zabudowaniach kościelnych na Ostrowie Tumskim funkcję administracyjnego centrum pełniła parafia Matki Boskiej Bolesnej i jej zabudowania. To tutaj wikariusz archidiecezji poznańskiej spotykał się z duchowieństwem wychodzącym z ukrycia, powierzał księżom administrację oswobodzonych parafii, jak również reprezentował archidiecezję poznańską wobec oficerów Armii Czerwonej oraz walczącego u jej boku Wojska Polskiego. Kronika parafialna potwierdza przyjęcie przez biskupa Walentego Dymka „radzieckiego generała” na skromnej, choć uroczystej kolacji w lutym 1945 roku. Prowadzący kronikę ks. Marian Frankiewicz nie wymienił wprawdzie nazwiska „,radzieckiego generała”, nie ma też pewności, czy był on rzeczywiście generałem, ale z pewnością parafia i probostwo były w tym czasie ważnym punktem na mapie oswobadzanego Poznania. Wkrótce do miasta wkroczyły też jednostki Wojska Polskiego, serdecznie witane przez mieszkańców Łazarza. Przy tej okazji ks. Marian Frankiewicz zapisał w kronice parafialnej spotkanie biskupa Walentego Dymka z generałem Michałem Rolą-Żymierskim, choć żadne inne źródła spotkania tego nie potwierdzają ${ }^{71}$.

W atmosferze radości i patriotycznego uniesienia 11 lutego 1945 roku na łazarskim rynku odbyło się uroczyste nabożeństwo polowe w intencji walczących o wyzwolenie Poznania. Wiadomo, że wojska radzieckie i polskie wystawiły na tę okazję poczty sztandarowe. Mszę odprawił biskup Walenty Dymek, kazanie zaś wygłosił ks. Marian Frankiewicz ${ }^{72}$.

Jeszcze przez wiele tygodni po zakończeniu II wojny światowej parafia Matki Boskiej Bolesnej na Łazarzu pełniła funkcję centrum administracyjnego archidiecezji poznańskiej. Do parafii przybył po powrocie do kraju 20 lipca 1945 roku arcybiskup poznański i prymas August Hlond. Na probostwie łazarskim rozmawiał w gronie najbliższych współpracowników o przyszłości Kościoła katolickiego Polsce i o jego powojennej organizacji, tutaj też 15 sierpnia 1945 roku prymas August Hlond mianował administratorów apostolskich prowincji kościelnych na tzw. ziemiach odzyskanych ${ }^{73}$.

radzieckich przeniesiono początkowo na cmentarz Górczyński, później zaś dokonano ich ekshumacji i przeniesienia do kwater żołnierzy radzieckich na cmentarzu wojskowym przy poznańskiej Cytadeli.

${ }^{71}$ AP MBB, M. Frankiewicz, Wspomnienia z lat okupacji, s. 44-45.

${ }^{72}$ AP MBB, Kronika parafii MB Bolesnej 1896-1958, cz. II (Suplement), karta „1945 rok”, s. 17. - Kronika parafialna stwierdza, że wśród uczestników mszy na Rynku Łazarskim 11 lutego 1945 roku widziano także generała Karola Świerczewskiego.

${ }^{73} \mathrm{Na}$ probostwie parafii akty nominacyjne odebrali biskupi: Bolesław Kominek (Opole), Andrzej Wronka (Gdańsk), Edmund Nowicki (Gorzów), Teodor Bensch (Warmia) oraz Karol Milik (Wrocław). Patrz także: P. Raina, Kościół w PRL. Kościól katolicki a państwo w świetle dokumentów 
Po wojnie parafia Matki Boskiej Bolesnej doświadczała szykan, jakie władze komunistycznej Polski stosowały wobec wspólnot kościelnych. Nakładano na nią podatki zwykłe i podatkowe domiary, poddawano licznym kontrolom administracyjnym i budowlanym. Nieznacznie zelżały one w latach 70 . $\mathrm{XX}$ wieku, ale wraz $\mathrm{z}$ wzrostem oporu społecznego przeciwko władzy komunistycznej w latach 70. XX wieku po objęciu probostwa łazarskiego przez ks. Bolesława Exlera (1982-2003) tutejsza parafia - jak za czasów pruskich - ponownie uznana została za wyjątkowo „niepokorną i trudną”, skupiając uwagę władz. Patriotyczne i niepodległościowe manifestacje, jakie trwały na jej terenie w latach 80 . XX wieku, były często pacyfikowane i rozpraszane przez oddziały milicji oraz ZOMO.

\section{RELIGIOUS LIFE OF THE INHABITANTS OF POZNAŃ UNDER GERMAN OCCUPATION ON THE EXAMPLE OF THE PARISH OF OUR LADY OF SORROWS}

\section{Summary}

The article presents the religious life of the inhabitants of Poznan in the years 1939-1945 on the example of the parish of Our Lady of Sorrows in Poznań (Lazarz). The moral and civic attitudes of the clergy and the faithful were discussed, their concern for ensuring the minimum of cultural needs, as well as the activities of the underground charitable and educational system in the occupied city. The text also presents the activity of the auxiliary bishop in the parish, Walenty Dymek, and the atmosphere of the last days of the occupation. The source basis of the article are resources of the Archives of the Parish of Our Lady of Sorrows in Poznan, few postwar articles as well as studies concerning the occupation and the discussed parish.

Słowa kluczowe: Alfons Jankowski, archidiecezja poznańska, Marian Frankiewicz, okupacja hitlerowska, parafia Matki Boskiej Bolesnej w Poznaniu, Stefan Stuligrosz, Walenty Dymek

Keywords: Alfons Jankowski, Archdiocese of Poznań, Marian Frankiewicz, Nazi occupation, parish of Our Lady of Sorrows in Poznań, Stefan Stuligrosz, Walenty Dymek 


\section{Bibliografia}

\section{Źródla archiwalne}

Archiwum Parafialne Parafii Matki Boskiej Bolesnej w Poznaniu

Frankiewicz M., Wspomnienia z lat okupacji 1939-1945, mps.

Kronika parafii MB Bolesnej 1896-1958, część I.

Kronika parafii MB Bolesnej 1896-1958, cz. II (Suplement), karta: Uzupełnienia do różnych lat. Materiały do Kroniki. Teczka I.

Sprawozdania duszpasterskie.

\section{Zbiory wlasne autora}

Wilczyński L., Historia parafii Matki Boskiej Bolesnej w Poznaniu, mps.

\section{Literatura}

Album Przewodnika Katolickiego, nr 14, 1903.

Banaszak M., Edmund Lorkiewicz (1907-1981), [w:] Duchowieństwo archidiecezji poznańskiej. Kapłani zmarli w latach 1946-2014, red. L. Wilczyński, Poznań 2014.

Banaszak M., Walenty Dymek, [w:] Księża spolecznicy w Wielkopolsce 1894-1919, t. I, red. M. Banaszak, Gniezno 1992.

Białecki K., Pod czujnym okiem bezpieki. Arcybiskup Walenty Dymek w materiałach WUBP w Poznaniu, [w:] Ksiadz Arcybiskup Walenty Dymek, Metropolita Poznański (1888-1956), red. L. Wilczyński, Poznań 2010.

Boras Z., Trzeciakowski L., W dawnym Poznaniu, Poznań 1974.

Dutkiewicz P., Tramwaje w Poznaniu, Poznań 2005.

Dworecki Z., Poznań i poznaniacy w latach Drugiej Rzeczpospolitej 1918-1939, Poznań 1994.

Epstein C., Wzorcowy nazista. Arthur Greiser i okupacja Kraju Warty, Wrocław 2010.

Jacewicz W., Woś J., Martyrologium polskiego duchowieństwa rzymskokatolickiego pod okupacja hitlerowska w latach 1939-1945, z. I: Straty osobowe, Warszawa 1977.

Jarkiewicz K., W ogniu wypróbowany 1939-1945, [w:] Dzieje Kościoła w Polsce, red. A. Wiencek, Bielsko-Biała 2008.

Jastrząb Ł., Życie religijne w Poznaniu podczas okupacji niemieckiej (1939-1945). Część I, „Poznańskie Zeszyty Humanistyczne”, t. XXIV, 2016.

Jastrząb Ł., Życie religijne w Poznaniu podczas okupacji niemieckiej (1939-1945). Część II, „Poznańskie Zeszyty Humanistyczne", t. XXV, 2016.

Jesse W., Wspomnienia pośmiertne. Ksiądz Alfons Jankowski. Jednodniówka, Poznań 1948.

Joachimczak W., Roman Hildebrandt (1908-1972), [w:] Duchowieństwo archidiecezji poznańskiej. Kapłani zmarli w latach 1946-2014, red. L. Wilczyński, Poznań 2014.

Kalendarz kościelny parafii Matki Boskiej Bolesnej na św. Łazarzu w Poznaniu, Poznań 1939.

Kędelski M., Ludność Lazarza i Górczyna w XIX i na początku XX wieku, „Kronika Miasta Poznania", nr 3: Święty Lazarz, 1998.

Kowal S., Społeczeństwo Łazarza w dwudziestoleciu międzywojennym, „Kronika Miasta Poznania”, nr 3: Swięty Lazarz, 1998.

Kowalski N., Szatkowski H., Kazimierz Maliński (1872-1928), [w:] Księża społecznicy w Wielkopolsce 1894-1919. Słownik biograficzny, t. II, red. L. Wilczyński, H. Szatkowski, Gniezno 2007. 
Kozłowski J., Józef Gorgolewski (1889-1942), [w:] Księża społecznicy w Wielkopolsce 1894-1919, t. I, red. M. Banaszak, Gniezno 1992.

Krajkowski L., Zabytkowy cmentarz górczyński parafii Matki Boskiej Bolesnej w Poznaniu 1910-2010, Poznań 2010.

Łuczak C., Pod niemieckim jarzmem (Kraj Warty 1939-1945), Poznań 1996.

Majka E., Pracowali w tej parafii..., „Wiadomości Parafialne Parafii Mosińskiej”, nr 146, 2013.

Marek R., Kościół rzymskokatolicki wobec ziem zachodnich i pótnocnych, Warszawa 1976.

Matusik P., Mater Dolorosa. U początków parafii Matki Boskiej Bolesnej na Świętym Łazarzu (1895-1913), „Kronika Miasta Poznania”, nr 3: Święty Lazarz, 1998.

Raina P., Kościót w PRL. Kościót katolicki a państwo w świetle dokumentów 1945-1989, t. I (lata 1945-1959), Poznań 1994.

Salmanowicz S., Prusy. Dzieje państwa i spoleczeństwa, Warszawa 1998.

Serwański E., Wielkopolska w cieniu swastyki, [w:] Zbrodnie niemieckie w Wielkopolsce 1939-1945, red. M. Libicki, R. Wryk, Poznań 2004.

Szatkowski H., Lewicki Jan Chrzciciel (1846-1909), [w:] Księża społecznicy w Wielkopolsce 1894-1919. Stownik biograficzny, t. III, red. H. Szatkowski, L. Wilczyński, Gniezno 2007.

Szymankiewicz Z., Poznań we wrześniu 1939 roku, Poznań 1985.

Śmigiel K., Duchowieństwo polskie w tzw. Okręgu Warty 1939-1945, [w:] Zbrodnie niemieckie w Wielkopolsce 1939-1945, red. M. Libicki, R. Wryk, Poznań 2004.

Trzeciakowscy M. i L., W dziewiętnastowiecznym Poznaniu. Życie codzienne miasta 1815-1914, Poznań 1982.

Trzeciakowski L., Lata międzywojenne, [w:] Poznań. Zarys dziejów, red. J. Topolski, Poznań 1973.

Trzeciakowski L., Stosunki polsko-niemieckie $w$ Wielkim Księstwie Poznańskim $w$ latach 1846-1848, [w:] W kręgu polityki. Polacy-Niemcy w XIX wieku, red. Lech Trzeciakowski, Poznań 2002.

Wilczyński L., Kardynat August Hlond - wrześniowy uciekinier?, „Poznańskie Zeszyty Historyczne", t. IX, 2007.

Wilczyński L., Ksiądz arcybiskup Walenty Dymek. Efekty inwigilacji, [w:] Ksiadz Arcybiskup Walenty Dymek, Metropolita Poznański (1888-1956), red. L. Wilczyński, Poznań 2010.

Wysiedlenie i poniewierka 1939-1945. Wspomnienia Polaków wysiedlonych przez okupanta hitlerowskiego z ziem polskich ,wcielonych” do Rzeszy, red. C. Łuczak, Poznań 1974.

Zakrzewski Z., Przechadzki po Poznaniu lat międzywojennych, Poznań 1983.

Zakrzewski Z., Ulicami mojego Poznania. Przechadzki z lat 1918-1939, Poznań 1985.

Zakrzewski Z., Wspominam Poznań. Fakty i refleksje, Poznań 1986.

Zarzycki A., Cyryl Ratajski (1875-1942), „Kronika Miasta Poznania”, nr 3, 1989.

\section{Teksty internetowe}

Piętka J., Alfons Jankowski (1907-1943), http://www.wtg-gniazdo.org/ksieza/main.php?akcja=opis\&id=1530 [dostęp: 22.06.2017].

Rudawski B., Alianckie naloty na Poznań, „Z Archiwum Instytutu Zachodniego”, nr 2, 2016, http:// www.iz.poznan.pl/plik,pobierz, 1276,flfc479f4ebf92e 52d4fd4d4332953df/nr\%202\%20-\%20 2016\%20-\%20Z\%20Archiwum\%20Instytutu\%20Zachodniego.pdf (dostęp 20.06.2017).

Śmigiel K., Losy Kościoła katolickiego w okupowanym Poznaniu, „Kronika Miasta Poznania”, nr 3, 2009, wydanie internetowe: https://wbc.macbre.net/document/6909/losy-koscioa-katolickiegow-okupowanym-poznaniu-ks-kazimierz-smigiel.html [dostęp: 21.06.2017]. 